\title{
India to challenge Basmati rice 'invention'
}

[NEW DELHI] India has been dragged into another dispute with the US Patents and Trademark Office, this time over the patenting of 'Basmati rice', the long-grain rice variety known for its distinct aroma and unique to the Indian subcontinent. It has only recently won a patents case over the plant turmeric (see Nature 389, 6; 1997).

The US seed company RiceTec, based in Alvin, Texas, claims to have "invented novel rice lines" whose grains have qualities of Indian Basmati and can be grown worldwide. US patent 5663484 would allow the company to market its aromatic rice as Basmati.

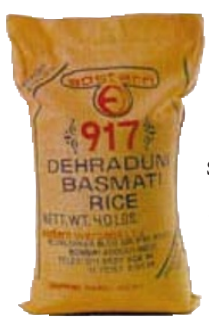

India says the US company is free to patent its aromatic rice under any name except Basmati, which it says is specific to the varieties grown for centuries by farmers in northern states of India and parts of Pakistan. It argues that the Rice row: Basmati name Basmati cannot be name in dispute. used to describe another product, even if it is similar to the Indian variety. But RiceTec claims that "Basmati is a generic name for a type of rice just as durum is for a type of wheat". It has dismissed Indian claims about uniqueness, saying aromatic rice grows worldwide.

RiceTec president Robin Andrews says the US patent is for an improved version of the "long-grain American Basmati rice" his company has already been selling under the brand names 'Texmati' and 'Kasmati'. Paula Coute, a spokesperson for the US patents office, says the RiceTec strain

\section{Call for moratorium on seedbank patents}

[LONDON] The United Nations Food and Agriculture Organization (FAO) is to consider a moratorium on patent applications for original varieties of seeds held on behalf of the international community by a network of international agriculture research centres.

The seeds are held in seedbanks run by the Consultative Group on International Agriculture Research (CGIAR), a network of research institutes mainly in the developing world but operated through the World Bank in Washington DC.

The call for the moratorium was made by
CGIAR, and will be considered at a meeting in June of the FAO's commission on genetic resources. It comes in the wake of attempts by research institutes in Australia to file claims to intellectual property rights on seeds borrowed from CGIAR seedbanks in India and Syria.

The patent applications were discovered by the environmentalist group RAF (Rural Advancement Foundation International), which alerted CGIAR and the FAO. The applications have since been withdrawn.

Pat Mooney, executive director of RAFI, welcomed the call for a moratorium. But plant breeders are sceptical. Bernard Le Buanec, secretary general of the International Plant Breeders' Association in Switzerland, questions the need for a moratorium on the grounds that international law already forbids the patenting of original varieties of germ plasm.

Geoffrey Hawtin, director general of the International Plant Genetic Resources Institute in Rome, says Le Buanec is "technically correct" but a moratorium will prevent patents being filed on original varieties of seed in countries where this is not illegal.

Ehsan Masood deserved to be called Basmati as it met the bility that must worry consumer groups. definition of Basmati.

But Indian officials say the patent would have a heavy impact on India's exports of Basmati, worth $\$ 800$ million a year. "What is worse is the negation of centuries of contributions by traditional farmers who have bred and cultivated Basmati," says Vandana Shiva, an expert in biodiversity with the environmentalist group Third World Network. She says real Basmati will now have to compete with "fakes" and substandard Basmati grown outside the subcontinent - a possiapproaches are being considered.

\section{'Give us back our mansion,' plead scientists}

[MOscow] A Russian court has partially complied with a complaint lodged against President Boris Yeltsin by scientists in the Theoretical Problems Department of the Russian Academy of Sciences. The scientists have been demanding the right to return to a property in Moscow from which they claim they were unlawfully removed.

In 1982 the academy built flats for 26 families formerly living in the building, and made repairs so that it could be occupied by a group of scientists headed by Professor Erast Adriankin. Yeltsin confirmed in 1991 through a decree that the mansion should belong to the scientists forever.

In January 1996, however, Yeltsin signed a new decree, according to which the building would be made available to official bodies, including representatives of the Chechen Republic. The scientists refused to leave and were removed by force. Their research programmes were disrupted.
The scientists took their complaint to an arbitration court, and in February 1997 Yeltsin's decree was cancelled. But the chairman of the court, Veniamin Yakovlev, disagreed with this decision, and the case was sent back for further investigation.

"We have been compelled to work at home without access to the documents and equipment left at our department," Adriankin said at the second court hearing. "We know that many of these have disappeared or been damaged. For two years we have not been receiving salaries, although we are working on important projects in space research and in research related to destruction of chemical weapons."

The court has now suggested that the department should get back just over a quarter of its former mansion. But the scientists remain dissatisfied. Adriankin says: "We shall continue our attempts to get back what belonged to us." Carl Levitin
The Indian government has promised that the patent will be challenged. A highlevel inter-ministerial group, including M.S. Swaminathan, the former director-general of the International Rice Research Institute in Manila, has been set up to present the country's case to the US patent office. Several

Scientists say one approach is to establish, through DNA fingerprinting, that the source of RiceTec's variety is the germ plasm from India accessed through international gene banks. "No one can breed Basmati without using original lines from us," says Suresh Sinha, former director of the Indian Agricultural Research Institute (IARI) in New Delhi.

Another approach being considered is to see whether RiceTec's patented variety measures up to the quality standards laid down for Basmati rice in India. E. A. Siddiqi, who has worked on the genetic improvement of Basmati for more than 20 years at IARI, says Basmati rice must pass seven tests.

India is also likely to initiate a dispute at the Geneva-based World Trade Organization. Suman Sahai, a geneticist and president of Gene Campaign, a non-governmental organization, says India and Pakistan should take the case to the organization's dispute settlement board on the grounds that patenting Basmati violates the protection offered to products that are 'geographically indicated' under the TRIPS international trade and intellectual property rights agreement.

Sahai claims that Basmati rice is exclusively associated with India and Pakistan in the same way as champagne is associated with France.

K.S.Jayaraman 